\title{
Owning Part but Losing All: Using Human Rights to Protect Home Ownership
}

\author{
Susan Bright, Nicholas Hopkins and Nicholas Macklam*
}

\section{Introduction}

In England the majority of householders live in homes that they own, with surveys demonstrating repeatedly the population's strong preference for home ownership over renting. ${ }^{1}$ Home ownership has been actively promoted by successive governments for a mix of ideological and political reasons, and the Coalition Government continues to present the opportunity to own as central to its housing strategy. ${ }^{2}$ Ownership is sold as providing the opportunity for wealth accumulation, a financial buffer, collateral that can be borrowed against, and supporting a sense of security and stability. ${ }^{3}$ Yet rising housing prices mean that traditional home ownership - the purchase of a home funded through the buyer's own resources and commercially available mortgage finance - has become the impossible dream for many. ${ }^{4}$ As a result, successive governments have sought to make this dream a reality by filling the affordability gap through Low Cost Home Ownership (LCHO) schemes.

One legal model for such schemes is "shared ownership", known colloquially as "partbuy, part-rent". ${ }^{5}$ Shared ownership schemes aim to offer the purchaser the opportunity to get a foot on the housing ladder, but are in fact a misnomer; there is no sharing of ownership at all. In return for an initial premium paid to a housing provider (most

\footnotetext{
* Professor of Land Law, University of Oxford; Professor of Law, University of Southampton; student member of Lincoln's Inn, respectively. The authors are grateful for the helpful comments received at the conference, and for the comments and assistance of Sarah Nield, Alistair Mills and the anonymous referee.

${ }^{1}$ A report issued by the Department for Communities and Local Government states that $86 \%$ would choose to buy if they had a free choice. See Department for Communities and Local Government, Public Attitudes to Housing in England: Report based on the results from the British Social Attitudes Survey (July 2011) p 5.

2 "For too long, millions have been locked out of home ownership. We want to build an economy that works for everyone, one in which people who work hard and play by the rules can expect town a decent home of their own”. See Department for Communities and Local Government, Laying the Foundations: A Housing Strategy for England (November 2011) p v (Foreword by the Prime Minister and Deputy Prime Minister).

${ }^{3}$ For a more detailed discussion, see S Bright and N Hopkins "Home, Meaning and Identity: Learning from the English Model of Shared Ownership” (2011) 28 Housing, Theory \& Society 377.

${ }^{4}$ The problem of affordability is recognised in the Government's Housing Strategy; see Department for Communities and Local Government, Laying the Foundations: A Housing Strategy for England (November 2011) pp 1 to 2.

${ }^{5}$ This is the most commonly used form of part ownership. In 2009-10 shared ownership accounted for 65\% affordable housing sales; see Homes and Communities Agency, Data Compendium: a collation of published data about affordable home ownership (June 2011) para 28.
} 
typically a housing association) ${ }^{6}$ the purchaser (referred to throughout this chapter as the "shared owner") is granted a "shared ownership lease" of a 99-year term. The premium paid for the lease (which may be funded using commercially available mortgage finance) is calculated according to the percentage of the market value of the property that the purchaser is able to afford (generally between $25-75 \%)^{7}{ }^{7}$ this is the share of the property that the shared owner is said to "own". A sub-market rent is then paid on the un-purchased share. ${ }^{8}$ The lease contains provisions which allow the shared owner to expand her "ownership" interest in the property through additional capital payments to the housing provider, known as "staircasing up" - the idea being that eventually the shared owner will have paid $100 \%$ of the market value of the property. It is only at this time that the shared owner will be entitled to have the freehold to the property transferred to her by the housing provider. $^{9}$

The shared ownership lease will usually be an assured tenancy under section 1 of the Housing Act 1988. ${ }^{10}$ This can be surprising; the assured tenancy regime is generally associated with short-term or periodic tenancies. Most long leases granted in exchange for an initial premium will be at a rent that excludes them from the assured tenancy regime, ${ }^{11}$ but the rent payable for a shared ownership lease will be above the level of the low rent exclusion. This means that a shared ownership lease can be ended only by court order on one of the grounds provided in schedule 2 to the Housing Act 1988, ${ }^{12}$ including Ground 8, which entitles the landlord to a possession order if two months' rent is unpaid. ${ }^{13}$ Possession under Ground 8 is mandatory; provided the rent arrears exist both at the time notice is served and at the date of the hearing, the court must order possession, even if it appears unreasonable on the particular facts. Research has shown that district judges dislike the mandatory nature of Ground $8,{ }^{14}$ but it is particularly unfair if used in the shared ownership context.

\footnotetext{
${ }^{6}$ Although the Tenant Services Authority now uses the term (Private) Registered Provider of Social Housing (PRPSH), following the Housing and Regeneration Act 2008, and housing associations previously were briefly known as Registered Social Landlords (RSLs), we refer to them throughout this chapter as housing associations, as the Department for Communities and Local Government continues to do.

${ }^{7}$ The average stake for purchases in 2009-10 was as 38.4\%: see Homes and Communities Agency, Data Compendium: a collation of published data about affordable home ownership (June 2011) para 22.

${ }^{8}$ The initial rent must not exceed $3 \%$ of the value of the un-purchased share: see Homes and

Communities Agency, Capital Funding Guide (2012-13) para 4.1.2.

${ }^{9}$ Where shared ownership concerns a flat, staircasing to $100 \%$ has the effect that the rent reduces to a minimum rent and the clauses of the lease connected to shared ownership cease to have effect. The shared owner is therefore left with a standard long lease of the flat.

${ }^{10}$ Lettings by social landlords come within the Housing Act 1988; it is only local authority lettings that are secure tenancies governed by the Housing Act 1985.

${ }^{11}$ Tenancies let at a low rent (£1,000 or less a year in London, $£ 250$ or less a year elsewhere) are not assured tenancies: Housing Act 1988, sch 1, para 3A(b). Some long residential leases granted in recent years will also be above the low rent limit (and thus, perhaps unexpectedly) come within the assured tenancy regime.

${ }^{12}$ Housing Act 1988, s 5.

13 The entitlement based on two months' unpaid rent is for rent payable monthly; if payable weekly, the requirement is eight weeks' unpaid rent; if payable quarterly or yearly, the requirement is one quarter's rent in arrears of more than three months and three month's rent in arrears of more than three months respectively.

${ }^{14} \mathrm{C}$ Hunter and others, "The exercise of judicial discretion in rent arrears cases” DCA Research Series 6/05 (October 2005) p 90.
} 
Richardson $v$ Midland Heart ${ }^{15}$ shows how Ground 8 can shatter the dreams of shared owners. In 1995 Miss Richardson paid £29,500 (representing 50\% of the market value of the property) for a 99-year shared ownership lease. Her husband was sentenced to eight years' imprisonment in 2003, and shortly after that she began receiving threats from his former associates. This led to her fleeing the property and residing at a women's refuge. As she no longer lived in the house, her housing benefit was stopped in February 2005 and rent arrears began to accrue. She unsuccessfully attempted to sell the property, ${ }^{16}$ which was then worth $£ 151,000$, and in the meantime arrears continued to build up. Finally, in January 2006 the housing association was granted possession of the property under Ground $8 .{ }^{17}$ At the time when the possession order was granted, Miss Richardson owed sixteen months’ rent arrears, amounting to £3,009.

Miss Richardson subsequently sought to recover her 50\% share in the property which by 2005 was valued at around $£ 75,000$. That claim was based on arguments of private law, all of which were rejected - albeit with regret - by Jonathan Gaunt QC, sitting as a Deputy High Court Judge. Miss Richardson did not, in fact, have any “ownership” of the home at all.

Miss Richardson lost everything - her home and her capital. The housing association received an unanticipated and unjust windfall: it did not simply get back the property, but also got to keep the value of Miss Richardson's share in the house. ${ }^{18}$ If this had been a forfeiture case, there would have been the possibility of relief against forfeiture, and in considering whether to grant relief courts take account of proportionality as well as the justice of the landlord retaining any advantage received from forfeiture. ${ }^{19}$ Alternatively, the court may have decided to order sale in preference to forfeiture (enabling Miss Richardson to retain her share of the value). ${ }^{20}$ Instead, the lease was ended and Miss Richardson got nothing.

Some may argue that there is no injustice here. Miss Richardson got the lease she bargained for. Possession and its consequences were part and parcel of that bargain; Miss Richardson ran the risk of possession if she became unable to pay the rent. We consider this argument to be inadequate as it does not take into account either the fact that there may be alternative options to possession that adequately protect the landlord's interests (which we raise in Part 2 of this chapter) or the wider context in which shared ownership has been promoted by governments as means of enabling those on low

\footnotetext{
15 [2008] L \& TR 31.

${ }^{16}$ Although the judge noted there was no evidence to support this view, he commented that it may not have sold because of "the state of repair and decoration ... [as] the house had suffered a degree of vandalism in Miss Richardson's absence”. See Richardson v Midland Heart [2008] L \& TR 31 at [6]. ${ }^{17}$ Midland Heart is not alone in using Ground 8 in shared ownership cases: see H Pawson and others, Rent arrears management practices in the housing association sector (Tenant Services Agency, March 2010) p 81.

${ }^{18}$ In Richardson, the housing association made an ex gratia payment to Miss Richardson of her initial premium, with rent arrears deducted. But, as noted by the judge ([2008] L \& TR 31 at [24]), this did not take into account Miss Richardson’s share in the uplift of the property’s value $(£ 45,000)$, which went to the housing association as a windfall.

${ }^{19}$ See Southern Depot Co Ltd v British Railways Board [1990] 2 EGLR 39, 44.

${ }^{20}$ See Khar v Delbounty Ltd (1998) 75 P \& CR 232; the landlord would have to account to the shared owner for the balance of the sale proceeds after deduction of costs and arrears.
} 
incomes to get onto the housing ladder, with the attendant prospect of asset appreciation and security.

Bright and Hopkins have previously shown that private law arguments are unlikely to enable Miss Richardson, and other shared owners in her situation, to recover the value of lost shares. ${ }^{21}$ Accordingly, this chapter focuses primarily on the question of whether public law can protect a shared owner's "investment value"22 in their property. This could be achieved by postponing possession temporarily to give the shared owner the opportunity to sell the property herself. Shared owners enjoy rights of alienation, albeit the leases are drafted to encourage the shared owner to sell the property to a purchaser nominated by their landlord rather than on the open market. Crucially, however, on a sale of the property the shared owner is entitled to receive the proceeds of sale in proportion to the share owned. Therefore shared owners have an expectation of receiving both their initial investment and any uplift arising through increases in the market value of the property (and carry the risk of a fall in property values). If possession has already been granted, then the question is whether public law can protect the investment value by enabling the shared owner to recover her share of the property's market value from the landlord. While our principal concern is with protecting the shared owner's investment, we also acknowledge that in some circumstances it might be (more) appropriate for the shared owner to be able to stay in the house, that is, for the "use value" 23 to be protected.

This chapter is structured as follows. Part 2 considers whether Article 8 of the European Convention on Human Rights (ECHR) (the right to respect for the home), or Article 1 of the First Protocol to the ECHR (A1P1) (the right to peaceful enjoyment of possessions), could be utilised to defend possession proceedings. In Part 3 we consider whether possession proceedings could be defended in the alternative through administrative law by questioning whether the decision to seek possession using Ground 8 could be said to be irrational or constitute breach of a legitimate expectation. Part 4 considers the scenario where a housing association has already recovered possession of shared ownership property and examines whether human rights arguments provide the basis for a claim which would allow the shared owner to recoup their share of the market value of the property, thereby protecting the investment value.

\section{Defending possession proceedings: ECHR}

This section looks at whether the shared owner can defend possession proceedings by using human rights law. We are not (necessarily) arguing that she should be able to stay in the property for the longer term - given that non-payment of rent involves breach of

\footnotetext{
${ }^{21}$ See S Bright and N Hopkins, "Richardson v Midland Heart Ltd: low cost home ownership - legal issues of the shared ownership lease” [2009] Conveyancer and Property Lawyer 337, discussing resulting and constructive trusts, Pallant $v$ Morgan trusts, estoppel, and unjust enrichment.

22 This term, and "use value" (to which we refer below), are discussed in more depth in S Bright and N Hopkins, "Home, Meaning and Identity: Learning from the English Model of Shared Ownership" (2011) 28 Housing, Theory \& Society 377. Put briefly, by “investment value” we mean the shared owner's financial interest in the property.

${ }^{23}$ By this we mean the importance attached by the shared owner to using the property as "home", as shelter, as the centre of community and so on.
} 
important lease obligations, this may be inappropriate. Instead, we are using the argument to buy time, preventing possession so that the shared owner has the chance to recoup the investment value of the property through sale.

The Human Rights Act 1998 (HRA 1998), through which the ECHR is given domestic effect, applies only to public authorities. In publicly funded shared ownership schemes the landlord is likely to be a housing association rather than a local authority, but the provisions of the HRA 1998 will usually still apply. Section 6(3)(b) of the HRA 1998 provides that a "public authority" for the purposes of the Act includes what some call "hybrid" public authorities, defined by the Act as "any person certain of whose functions are of a public nature". The leading case on what may constitute a "hybrid" public authority is $R$ (Weaver) $v$ London Quadrant Housing Trust, ${ }^{24}$ in which the Court of Appeal formulated a number of factors which are indicative of a body that exercises "public functions". These include: whether the body is in receipt of public funds; whether the body may exercise statutory powers; whether the body provides a public service; and whether the body undertakes a role similar to that of central government or a local authority. The court also stated that the concept of a hybrid public authority is to be given a "broad and generous interpretation". ${ }^{25}$

Many non-profit housing associations receive social funding in the form of social housing grants, provide subsidised housing (which is a governmental function), have charitable status and act in the "public interest"; as well as being able to exercise certain statutory powers, such as applying for Anti-Social Behaviour Orders. ${ }^{26}$ Following Weaver it is therefore likely that non-profit housing associations which offer shared ownership leases will be classified as "hybrid" public authorities under section 6(3)(b) the HRA 1998.

However, it is not sufficient that the housing association performs a public function and is a hybrid public authority; the particular act in question (allocation of housing, termination, etc) must also be a public act rather than a private one. ${ }^{27}$ Following Weaver, seeking possession is highly likely to constitute a public act: the act of terminating a social tenancy ${ }^{28}$ is so bound up in the function of providing social housing that, if the latter constitutes a "public function", the former must constitute a "public act" ${ }^{29}$ This chapter therefore proceeds on the basis that a shared ownership lease may only be terminated in a way which is consistent with the shared owner's rights under the ECHR.

\subsection{Article 8 of the ECHR}

Article 8 has in recent years been used frequently to challenge possession proceedings brought by social landlords. A sustained clash between the European Court of Human

\footnotetext{
24 [2009] EWCA Civ 587, [2010] 1 WLR 363.

${ }^{25}$ Ibid at [72].

${ }^{26}$ Crime and Disorder Act 1998, s 1(1A)(ca).

${ }^{27}$ Human Rights Act 1998, s 6(5).

${ }^{28}$ The Housing and Regeneration Act 2008, ss 68 and 70 classifies shared ownership as social housing.

${ }^{29}$ See $R$ (Weaver) v London Quadrant Housing Trust [2009] EWCA Civ 587, [2010] 1 WLR 363 at [76]

to [80]. Although Weaver involved termination of an assured tenancy, the argument applies equally to the allocation and termination of LCHO products.
} 
Rights (ECtHR) and domestic courts ${ }^{30}$ was finally brought to an end by a nine Justice Supreme Court in Manchester City Council v Pinnock, where it was held that any "person at risk of being dispossessed of his home at the suit of a local authority should in principle have the right to raise the question of the proportionality of the measure, and to have it determined by an independent tribunal in the light of article 8". ${ }^{31}$ Soon afterwards came the seven person Supreme Court decision in Hounslow LBC v Powell ${ }^{32}$ which focused on the practical application of Pinnock.

There has yet to be a reported decision on whether an Article 8 defence raised in the context of proceedings brought under Ground 8 requires the court to consider proportionality in deciding whether to order possession. However, the results of Pinnock and Powell suggest it does. In both cases the tenants had no security, ${ }^{33}$ and although the relevant statutory provisions seemingly gave no discretion to the court (like Ground 8), it was held that they must be read in such a way to enable a court to take account of proportionality if Article 8 was raised. ${ }^{34}$ Therefore, following Pinnock and Powell it appears that where a mandatory ground for possession (such as Ground 8) is relied upon, proportionality must be considered if the tenant relies on Article 8 as an arguable defence.

\subsubsection{The substantive challenge under Article 8}

\section{Article 8 reads:}

Everyone has the right to respect for his private and family life, his home and his correspondence.

There shall be no interference by a public authority with the exercise of this right except such as is in accordance with the law and is necessary in a democratic society in the interests of national security, public safety or the economic wellbeing of the country, for the prevention of disorder or crime, for the protection of health or morals, or for the protection of the rights and freedoms of others.

\footnotetext{
${ }^{30}$ See S Nield, “Clash of the Titans: Article 8, Occupiers, and Their Home” in S Bright (ed), Modern Studies in Property Law: Volume 6 (Hart 2011).

${ }^{31}$ [2011] UKSC 6, [2010] 3 WLR 1441 at [45].

32 [2011] UKSC 8, [2011] 2 WLR 287.

33 Pinnock concerned a demoted tenancy; Powell involved introductory tenancies and a tenant housed under Part 7 of the Housing Act 1996.

${ }^{34}$ In Pinnock this was achieved by using section 3 of the HRA 1998 to "read in" to the legislation a requirement that the notice procedure had to be "lawfully followed", which allowed consideration of "whether the procedure had been lawfully followed, having regard to the defendant's article 8 rights ...." (see Lord Neuberger at [2011] UKSC 6, [2010] 3 WLR 1441 at [77]). This approach was followed by Lord Hope in Powell (at [2011] UKSC 8, [2011] 2 WLR 287 at [56]). However, Lord Phillips (who wrote a minority concurring judgment in Powell) appeared to approach the task of interpretation in a different manner. He stated (at [2011] UKSC 8, [2011] 2 WLR 287 at [98]) that "the precise formulation of the proviso required by article 8 is of no significance ... compatibility can be achieved ... by implying the phrase 'provided that article 8 is not infringed'”.
} 
Where a public authority seeks possession of a person's home, Article 8 is engaged due to the interference with the tenant's "home" rights. ${ }^{35}$ Any measure which interferes with Article 8 rights must pursue a legitimate aim in accordance with the law by answering a "pressing social need" and the measure used to pursue that aim must be "necessary in a democratic society". In practice this is now taken to mean that it is necessary to show both that possession pursues a legitimate aim and is a proportionate means of achieving that aim.

\subsubsection{Pursuit of a legitimate aim}

In Pinnock it was said that "there will be no need, in the overwhelming majority of cases, for the local authority to explain and justify its reasons for seeking a possession order." 36 This view was based on the fact that, in the majority of cases, the twin aims identified in Pinnock were satisfactory for Article 8 purposes. Those twin aims were: first, vindicating the authority's ownership rights; and secondly, enabling the authority to comply with its public duties in relation to the allocation and management of its housing stock. ${ }^{37}$

But shared ownership operates very differently from the social housing statutory regimes under consideration in the Pinnock and Powell cases. ${ }^{38}$ In Powell Lord Hope placed emphasis on the fact that Parliament had already carefully decided who is to have security and who is not under the Housing Act 1985 to reflect the perceived housing management needs of local authorities. ${ }^{39}$ This is not the case with shared ownership. First, no particular Parliamentary attention has been given to the way in which shared ownership is structured legally. ${ }^{40}$ Secondly, shared owners have not been deliberately placed into a class of occupiers for whom there is no security, unlike the occupiers under consideration in Pinnock and Powell. The absence of security is probably an unanticipated consequence of the legal model used to deliver shared ownership. It is likely that prior to Richardson most people would have assumed that termination of a shared ownership lease would be governed by the usual rules on forfeiture, giving the possibility of relief against forfeiture being available. Indeed, it is notable that only after the decision in Richardson was a "key information" sheet annexed to the standard model leases, which includes the warning:

"You need to be aware that if the Leaseholder fails to pay the rent reserved by the Lease and/or fails to observe and perform his or her obligations in the Lease the Landlord may be entitled to terminate the lease (subject to the Landlord obtaining any necessary court order). If the lease is terminated the Leaseholder

\footnotetext{
35 See Kay v United Kingdom (2012) 54 EHRR 30 at [68]: “The loss of one's home is the most extreme form of interference with the right to respect for the home”.

${ }^{36}$ Manchester City Council v Pinnock [2011] UKSC 6, [2010] 3 WLR 1441 at [53].

${ }^{37}$ Ibid at [52].

${ }^{38}$ The demoted and introductory tenancies under consideration in Pinnock and Powell were set up to deal with the problem of anti-social behaviour; the licence granted under the homelessness legislation in Powell was part of the response to the need for housing authorities to be able to respond flexibly and quickly to homelessness situations.

${ }^{39}$ Hounslow LBC v Powell [2011] UKSC 8, [2011] 2 WLR 287 at [10].

${ }^{40}$ As we note above, at p 2, it is surpising that the shared ownership lease falls within the assured tenancy regime.
} 
will lose (and will not be entitled to any compensation for), any shares in the property which he or she had acquired”. ${ }^{41}$

Thirdly, the first aim in Pinnock is to do with vindication of ownership - in shared ownership cases, ownership itself is split between the housing association and the tenant. ${ }^{42}$ Fourthly, account should be taken of the aim of shared ownership: unlike rental social housing it is about more than simply providing a roof over one's head; it is also intended to enable a capital asset to be built up. ${ }^{43}$

In practice, both European and domestic courts readily find that there is a legitimate aim, and in Pinnock and Powell the Supreme Court, although cautious about use of the language of "exceptionality", clearly thought that in "virtually every case" a possession order would be proportionate. ${ }^{44}$ However, this evaluation was, as the Justices were careful to note, context specific. In the context of the kind of housing management issues involved in those cases and the statutory schemes involved, it is unsurprising that very strong weight would be attached to the two legitimate aims identified and that when it came to the balancing exercise involved in proportionality only very special (exceptional) personal circumstances were likely to lead to a finding of disproportionality.

In shared ownership cases quite different considerations are involved; shared ownership properties are not part of the regular rented housing stock that is seen as available for housing those in need or on waiting lists. Rather, they are made available to facilitate entry into the home ownership market, and involve potential loss of housing stock if the purchaser eventually "staircases" up to a full equity share.

If the shared owner is in arrears with rent, although it may appear reasonable to recover possession in order to vindicate the landlord's ownership rights and to protect the economic well-being of the country, ${ }^{45}$ there may be other, less intrusive, measures that could be taken in order to achieve these legitimate aims. This includes, most obviously, allowing the shared owner to sell the property or alternatively using the more flexible remedy of forfeiture (as against a mandatory ground for possession like Ground 8). More imaginative means of protecting the landlord's financial interests could also be explored: for example, utilising a sale and rent-back arrangement or converting the rent arrears into a larger equity share for the landlord. This raises a further issue: although the aims of possession are legitimate, is it proportionate that the housing association should acquire a windfall at the expense of the shared owner?

\footnotetext{
41 The Key Information sheet is available at: http://www.homesandcommunities.co.uk/cfg?page_id=6169\&page=155 (last accessed 28 May 2012).

42 For more detailed information on this point, see S Bright and N Hopkins "Home, Meaning and Identity: Learning from the English Model of Shared Ownership” (2011) 28 Housing, Theory \& Society 377.

${ }^{43}$ See pp 1 and 3 above.

${ }^{44}$ Manchester City Council v Pinnock [2011] UKSC 6, [2010] 3 WLR 1441 at [54]. In Hounslow LBC v Powell [2011] UKSC 8, [2011] 2 WLR 287 at [41] Lord Hope said that the twin aims identified in Pinnock "should always be taken for granted" and only if a "seriously arguable" defence is put forward, based on "factual objections" and "personal circumstances", will the court need to adjourn the case to consider issues of "lawfulness or proportionality".

45 This combination of legitimate aims was accepted by the ECtHR in Kryvitska and Kryvitskyy v Ukraine (App No. 30856/03) (unreported) at [56].
} 


\subsubsection{Proportionality}

As Hickman notes, despite having now accepted proportionality as a principle of English public law, domestic courts have yet to formulate a clear and principled approach to proportionality. ${ }^{46}$ In Powell the Supreme Court was invited to adopt the structured approach to proportionality developed in the leading immigration case of Huang $v$ Secretary of State for the Home Department. ${ }^{47}$ This would have required consideration of whether the grant of possession, taking full account of all considerations weighing in favour of the occupant, would prejudice the occupier's right to respect for the home in a manner sufficiently serious to amount to a breach of the fundamental rights protected by Article 8. In Powell this was expressly rejected by Lord Hope, for fears that it would give rise to the risk of prolonged and expensive litigation and therefore, "in the context of a statutory regime that has been deliberately designed by Parliament", it would be wholly inappropriate. But, as noted above, the statutory regime that governs shared ownership leases has not been "deliberately designed by Parliament”, unlike those being considered in Powell. As a result, it could be said that the structured approach to proportionality developed in Huang may well be appropriate for shared ownership cases, notwithstanding its rejection in Powell.

In the more usual (non-shared ownership) tenancy possession cases the argument that possession would be disproportionate would have to take into account the particular context in which the possession claim is being made, including considerations such as how long the occupier has been living in the home, whether there are children involved, the health of the occupier, particular vulnerabilities, and so on.

Of course, some of these personal and context specific considerations may be equally applicable to the shared owner's claim that possession will be disproportionate. But the primary argument for the shared owner is a bigger one: that it will always be disproportionate to use Ground 8 where shared ownership is in issue. In the shared ownership context, when the landlord recovers possession, the occupier does not merely lose the roof over her head (the use value). ${ }^{48}$ Home ownership offers financial benefits, in particular the investment value, as well as non-financial benefits, such as providing a sense of place and permanence. ${ }^{49}$ For the shared owner, the ability to build a capital asset is integral to the meaning of "home". It is this combination of impacts that makes it likely that mandatory termination of the lease, with the concomitant loss of the shared

\footnotetext{
46 T Hickman, "The structure and substance of proportionality” [2008] Public Law 694, 695.

47 [2007] UKHL 11, [2007] 2 AC 167. The approach to proportionality in Huang was itself developed from the Privy Council's formulation of proportionality in de Freitas v Permanent Secretary of Ministry of Agriculture, Fisheries, Lands and Housing [1999] 1 AC 69, which requires that the means used to impair the right must go no further than is necessary to accomplish the legitimate aim. This formulation, known as the "minimal impairment test" has been cited with approval in numerous House of Lords cases and has been described as "firmly established as the test of proportionality in domestic law": T Hickman, “The structure and substance of proportionality” [2008] Public Law 694, 701.

${ }^{48}$ In the Richardson case, Miss Richardson had had to leave her home and so it no longer provided "use value” to her, but the other values associated with home ownership remained.

${ }^{49}$ For fuller discussion, see S Bright and N Hopkins "Home, Meaning and Identity: Learning from the English Model of Shared Ownership” (2011) 28 Housing, Theory \& Society 377.
} 
owner's share in the property, will be found to disproportionate and in breach of the shared owner's Article 8 rights.

Admittedly, this argument relies on an expansive understanding of "home" within Article 8. Existing ECtHR case law shows that "home" has an autonomous meaning, as a place of residence with which the individual has "sufficient and continuing links"50 and it has also been given a broad interpretation at domestic level. ${ }^{51}$ These links are not dependent on, or limited by, property rights, but look to the social and psychological attachment a person has with a dwelling and its location. ${ }^{52} \mathrm{~A}$ home is "not just a place where one lives but also the place where one feels one belongs". ${ }^{53}$ While "home" may begin with the physical structure, it also embodies values closely associated with personhood. The idea of home within Article 8 can thus readily encompass the nonfinancial benefits that flow from home ownership. Our argument is that, in addition, taking account of the policy reasons underlying the promotion of LCHO and the emphasis placed by successive governments on the idea of it providing a secure nest egg, the courts' interpretations of "home” could - and should - be developed to reflect the investment value.

\subsection{Article 1 of the First Protocol to the ECHR}

In contra-distinction to Article 8, the investment value connected to home ownership, but not the non-financial benefits, fits readily within the ambit of A1P1.

A1P1, entitled “protection of property”, reads:

Every natural or legal person is entitled to the peaceful enjoyment of his possessions. No one shall be deprived of his possessions except in the public interest and subject to the conditions provided for by law and by the general principles of international law.

The preceding provisions shall not, however, in any way impair the right of a State to enforce such laws as it deems necessary to control the use of property in accordance with the general interest or to secure the payment of taxes or other contributions or penalties.

The protection of "possessions" in the first sentence of A1P1 guarantees, in substance, the right to property. ${ }^{54}$ Within its scope fall all rights and interests constituting assets, broadly understood, as explained by the ECtHR in Stretch $v$ United Kingdom:

The Court recalls that, according to the established case law of the Convention organs, "possessions” can be "existing possessions" or assets, including claims, in

\footnotetext{
${ }^{50}$ Gillow v United Kingdom (1986) 11 EHRR 335.

${ }^{51} R$ (Countryside Alliance) v Attorney General [2007] UKHL 52, [2008] 1 AC 719, 745, citing Niemietz $v$ Germany (1993) 16 EHRR 97 to illustrate that "home” can “... cover premises other than the place where a person lays his or her head at night".

${ }^{52}$ A Busye, "Strings Attached: The Concept of Home in the Case Law of the ECHR" (2006) European

Human Rights Law Review 294.

53 Ibid 296.

${ }^{54}$ Marckx v Belgium (1979) 2 EHRR 330 at [63].
} 
respect of which the applicant can argue that he has at least a "legitimate expectation" of obtaining effective enjoyment of a property right. ${ }^{55}$

In order for a shared owner to use A1P1 to prevent the lease being ended, it would have to be shown that termination is an interference with "possessions" (the "interference" question), which is not "in the public interest" (the "justification" question). In substance, the justification question leads to a proportionality analysis. The "possession" that we argue is interfered with is the shared ownership lease and all the rights of ownership flowing from the lease as a legal estate. This includes the power to sell and to recoup the investment at the current market value. In this way the shared owner's interest in the investment value of the property is brought into play directly, rather than requiring it to be introduced indirectly as an element of the shared owner's home rights under Article 8.

Although in Pinnock and Powell the Supreme Court was considering Article 8 only, it follows as a matter of principle that domestic courts must be similarly required to consider whether making a possession order would breach the occupier's A1P1 rights where it is engaged and an arguable defence is raised. ${ }^{56}$

\subsubsection{The "interference" question}

Although this is not evident from the wording of A1P1, the ECtHR has treated A1P1 as containing three rules:

The first rule, which is of a general nature, enounces the principle of peaceful enjoyment of property; it is set out in the first sentence of the first paragraph.

The second rule covers deprivation of possessions and subjects it to certain conditions; it appears in the second sentence of the same paragraph.

The third rule recognises that states are entitled, amongst other things, to control the use of property in accordance with the general interest, by enforcing such laws as they deem necessary for the purpose; it is contained in the second paragraph. ${ }^{57}$

The approach of the ECtHR is to classify an interference with possessions under one or more of these three rules. The second rule ("deprivation" of possessions) is said to apply to someone who is deprived of ownership, meaning "the extinction of all the legal rights of the owner by operation of law or the exercise of a legal power to the same effect". ${ }^{58}$ In contrast, the third rule ("control of use" of possessions) typically involves the elimination of one of the incidents of ownership, thus constituting interference with

\footnotetext{
55 (2004) 38 EHRR 12 at [32].

${ }^{56}$ In the same manner as discussed at p 6 above in relation to Article 8.

57 Sporrong and Lonnroth $v$ Sweden (1983) 5 EHRR 35 at [61] (emphasis added).

58 See R Clayton and H Tomlinson, The Law of Human Rights: Volume 1 (2nd ed, OUP 2009) para 18.104, citing Lithgow v United Kingdom (1986) 8 EHRR 329 at [107].
} 
possessions, but not to the extent required under the second rule. ${ }^{59}$ Examples of measures which have been held to constitute a "control of use" include planning controls $^{60}$ and rent control. ${ }^{61}$

The analytical value of approaching A1P1 on the basis of three separate rules has been questioned, and in some cases the ECtHR considers it unnecessary to decide whether an interference falls within the second or third rules, pointing out that the second rule is merely a specific example of the general principle enunciated in the first rule. ${ }^{62}$ However, in other cases the classification as to which "rule" the case falls under has been influential on the outcome, because interferences falling under the second rule may be subject to a proportionality inquiry of a greater intensity than those falling within the third rule ${ }^{63}$ - in particular, in the absence of compensation to justify a deprivation of possessions the ECtHR will almost always find that A1P1 has been breached. ${ }^{64}$

On first impressions it may seem obvious that the termination of a lease which results in a shared owner losing her home and - importantly - losing the "share" that she has bought in the property, will be a deprivation of possessions and will therefore not be justified in the absence of compensation. However, it is far from clear that this is the case, and there are two particular difficulties in the analysis.

The first difficulty relates to classification: under the ECtHR's A1P1 jurisprudence it is not straightforward into which of the rules any particular interference will fall. This is illustrated by JA Pye (Oxford) Ltd v United Kingdom. ${ }^{65}$ The majority in the Grand Chamber of the ECtHR held that the English scheme of adverse possession constituted a "control of use" of property under the third rule. ${ }^{66}$ This contrasts with the analysis of the

\footnotetext{
${ }^{59}$ There is, of course, a considerable literature about the nature of ownership. Harris argues that there is an "ownership spectrum", which ranges from "mere property" to "full-blooded ownership". Where one falls on that spectrum depends upon the nature and extent of the "property-limitation" and "expropriation" rules to which a particular item of property is subject, and the nature and extent of the "open-ended" use privileges and powers to control the "owner" is said to enjoy in relation to that property (see J W Harris, Property and Justice (OUP 1996)). However, the "bundle of rights" view is still the dominant theoretical view. This sees property as comprised of a multiplicity of rights rather than a single, unitary right of "property" or "ownership", i.e. a right to possess, a right to use, a right to manage, a right to the income, a right to the capital, a right to alienate, a right to security, and so on. See A M Honoré, Making Law Bind: Essays Legal and Philosophical (Clarendon 1987). For supporters of this approach see: J Waldron, The Right to Private Property (Clarendon 1998) pp 47 to 53, 59 to 60; L Becker, Property Rights: Philosophic Foundations (Routledge 1977) pp 11 to 21; S Munzer, A Theory of Property (CUP 1990) pp 22 to 36. Adopting this analogy, taking one of these sticks from the bundle is likely to be a control of use; taking all of the sticks will be a deprivation. Where the line is to be drawn is unclear.

${ }^{60}$ Pine Valley Developments v Ireland (1991) 14 EHRR 319.

${ }^{61}$ Mellacher v Austria (1990) 12 EHRR 391.

${ }^{62}$ See R Clayton and H Tomlinson, The Law of Human Rights: Volume 1 (2nd ed, OUP 2009) para 18.99 citing Beyeler v Italy (2001) 33 EHRR 52 at [106] and Broniowski v Poland (2005) 40 EHRR 21 at [135] to [136]. See also Gladysheva v Russia [2012] HLR 19 at [71].

${ }^{63}$ See R Clayton and H Tomlinson, The Law of Human Rights: Volume 1 (2nd ed, OUP 2009) para 18.131.

${ }^{64}$ See p 14 and following below.

${ }^{65}$ (2008) 46 EHRR 45 (Grand Chamber).

${ }^{66}$ The case concerned adverse possession as it operated within the regime of the Land Registration Act 1925 (the later Land Registration Act 2002 operates differently). It was decided on the basis that the proportionality test was satisfied: a fair balance had been struck between the interests of the individuals
} 
Chamber which had held that the cumulative effect of the statutory provisions of the Land Registration and Limitation Acts was to transfer beneficial ownership of the land from one individual to another and therefore constituted a deprivation of possessions (within the second rule). ${ }^{67}$ The fact that the Grand Chamber preferred the analysis that there was a control of use (the third rule) demonstrates the difficult task in drawing the line between the three rules.

Domestic courts have not devoted much attention to the issue of what exactly constitutes "control of use". ${ }^{68}$ Instead a common sense approach has been taken; it has been stated (in a context outside of A1P1) that "whether a law or exercise of an administrative power does amount to a deprivation of property depends of course on the substance of the matter rather than upon the form". ${ }^{69}$ This suggests that a domestic court would treat the termination of a lease as falling within the second rule of deprivation of possessions. Indeed, subject to the discussion below on the "inherent limitation" difficulty, it is hard to see how it could be seen as anything other than a deprivation of possessions. Pennycook v Shaws (EAL) Ltd implicitly supports this view, as the Court of Appeal held that the service of a counter-notice under the Landlord and Tenant Act 1954 which had the effect of denying the tenant of the opportunity to renew its lease (effectively bringing the leasehold relationship to an end) was a deprivation of possessions, albeit justified on the facts. ${ }^{70}$

The second difficulty relates to a doctrine known as "inherent limitation": ${ }^{71}$ when the interference reflects a burden or qualification to which the possession was already subject at the point of acquisition, this will not count as an interference with possessions and as a result A1P1 will not be engaged. An example might be that if a purchaser acquires land which is subject to a right of way, he cannot then complain that his land is

and the community. However, the court was split 10:7, with a dissenting judgment arguing that a fair balance had not been struck, in large part down to the absence of compensation for the holder of the paper title. The majority considered that compensation was only an important factor in second rule (deprivation of possessions) cases; the dissenting judgment disagreed. Arguably, if the case were categorised as falling within the second rule, the absence of compensation would have tipped the balance in the proportionality inquiry.

67 (2006) 43 EHRR 3 (Chamber) at [60].

68 Although they have followed the Strasbourg jurisprudence in treating adverse possession as a "control of use”. See Ofulue v Bossert [2008] EWCA Civ 7, [2009] Ch 1.

${ }^{69}$ See Grape Bay Ltd v Attorney-General of Bermuda [2000] 1 WLR 574 (PC) 583. This concerned a complaint that a legislative provision preventing the applicant from running a franchise in Bermuda was a deprivation of property without compensation under the Constitution of Bermuda.

${ }^{70}$ [2004] EWCA Civ 1000, [2004] Ch 296. On the other hand, it is difficult to distinguish the Grand Chamber's decision in Pye: there are clearly differences between Pye and Pennycook/shared ownership cases at a formal level, but it is hard to see the substantive differences as the practical outcome in each is the removal of all ownership powers from the (former) owner/tenant.

${ }^{71}$ This term is not intended to refer to the doctrine of implied limitations on Convention rights, which provides that certain rights which appear "absolute" under the Convention are in fact subject to implicit limitations. This doctrine appears most frequently in the ECtHR's case law on access to the courts under Article 6 of the Convention. For example, in Golder $v$ United Kingdom the ECtHR said "The Court considers,...that the right of access to the courts is not absolute. As this is a right which the Convention set forth without, in the narrower sense of the term, defining it, there is room, apart from the bounds delimiting the very content of any right, for limitation permitted by implication.” See R Clayton and $\mathrm{H}$ Tomlinson, The Law of Human Rights ( $2^{\text {nd }}$ ed 2009) para 6.202 and following. 
interfered with when that right of way is exercised. ${ }^{72}$ The challenge is to explain where the line is drawn between an interference, such as the exercise of an easement, that should not engage A1P1 and an interference that should.

As Harris points out, all ownership rights in land are subject to property limitation rules and expropriation rules; for example, the risk of compulsory purchase. ${ }^{73}$ If land is bought and later taken by compulsory purchase, this is something that should be treated as an interference with possessions so as to engage A1P1 (although as compensation is paid under compulsory purchase laws, the interference will most likely be justified). To argue that compulsory purchase is not an interference on the basis that the land (possession) was inherently limited by this possibility even when originally bought would be a nonsense as it denudes A1P1 of any sensible content. ${ }^{74}$ Yet, as Goymour and Gardner both illustrate, there is no convincing way to articulate exactly when the "inherent limitation" argument will prevent there being an interference with possessions and when it will not. ${ }^{75}$ At the end of the day, it may come down to little more than a legally based intuition that termination of a shared ownership lease is the sort of interference that engages A1P1.

\subsubsection{The "justification" question}

Any interference with the rights protected by A1P1 must be justified. In Stretch $v$ United Kingdom the ECtHR explained that "an interference must strike a "fair balance" between the demands of the general interests of the community and the requirements of the individual's fundamental rights". ${ }^{76}$

There are two connected issues here. First, any deprivation must be in the public interest; legislative measures which interfere with possessions must be subject to conditions provided for by law and pursue a legitimate aim. As discussed above in relation to Article 8, a housing association would most likely seek to advance as its legitimate aims for taking possession proceedings against a shared owner the protection of its ownership rights coupled with protecting the economic well-being of the country. ${ }^{77}$

The second connected issue is that the interference must strike a "fair balance" between the interests of the community and individual rights. In substance this amounts to a proportionality analysis: the means employed must be proportionate to the aims pursued and not impose an excessive burden on an individual. The provision of compensation is relevant to the fair balance inquiry: a "deprivation of possessions" under the second rule

\footnotetext{
${ }^{72}$ See Aston Cantlow and Wilmcote with Billesley Parochial Church Council v Wallbank [2003] UKHL 37, [2004] 1 AC 546.

${ }^{73}$ See J W Harris, Property and Justice (OUP 1996) pp 33 to 38.

${ }^{74}$ In Wilson v First County Trust Ltd (No 2) [2003] UKHL 40, [2004] 1 AC 816 at [41] to [42] Lord Nicholls commented that the proposition that A1P1 is not engaged where a property is acquired subject to limitations under the national law which subsequently bite would mean that a "convention right guaranteeing a right to property would have nothing to say. That is not an attractive conclusion". ${ }^{75}$ See A Goymour, "Property and Housing" in D Hoffman (ed), The Impact of the UK Human Rights Act on Private Law (CUP 2011) and S Gardner, An Introduction to Land Law (3rd ed, Hart 2012) pp 32-33. 76 (2004) 38 EHRR 12 at [37].

77 See p 7 and following above.
} 
is unlikely to be proportionate if no compensation is paid. ${ }^{78}$ The presence of procedural safeguards is also relevant: the ECtHR has stated that A1P1 requires that the individual must be given reasonable opportunity to put their case forward, "for the purpose of effectively challenging the measures interfering with the rights guaranteed ...”.79

The mandatory nature of Ground 8 is important in this context. ${ }^{80}$ Similarly, if the termination of a shared ownership lease invokes the second rule of A1P1, the absence of any compensation means that to grant possession, and thereby terminate the lease, is likely to be found disproportionate. Even if termination of the lease is (improbably) categorised as falling under the third rule, the absence of compensation may nevertheless violate the fair balance requirement. ${ }^{81}$

\subsection{The likelihood of success}

Both Article 8 and A1P1 present challenges, quite apart from predicting how a judge would decide the issue of proportionality. Success under Article 8 would rely upon the court giving "home” an expansive definition incorporating not just "use value” but also the "investment value". A1P1 requires no such judicial creativity - the protection afforded to "possessions" under A1P1 can encompass both. ${ }^{82}$ However, although A1P1 might seem a more natural Convention right to apply in the shared ownership context, the intensity of review differs from that under Article 8. Certainly at the level of the ECtHR it is recognised that national authorities should have space to choose how to protect Convention rights, but that this space or "margin of appreciation" will be narrower when a right of central importance, such as the right to respect for the home, is concerned. ${ }^{83}$ As a result, domestic courts are likely to adopt a stricter intensity of review when dealing with an argument based on Article $8 .^{84}$ Nonetheless, using a mandatory statutory ground for ending the shared ownership lease, with all of the emotional and financial consequences that entails, is likely to be disproportionate even in the light of the more relaxed scrutiny of A1P1, particularly since the housing association may have less intrusive means of advancing its legitimate aims. ${ }^{85}$ This then leads on to the

\footnotetext{
${ }^{78}$ See James $v$ United Kingdom (1986) 8 EHRR 123 at [54].

79 Jokela v Finland (2003) 37 EHRR 26 at [45] (emphasis added).

${ }^{80}$ In Zehentner $v$ Austria (2011) 52 EHRR 22 at [73] the ECtHR said: "Moreover, the Court reiterates that although art 1 of Protocol No 1 contains no explicit procedural requirements, the proceedings at issue must afford the individual a reasonable opportunity of putting his or her case to the relevant authorities for the purpose of effectively challenging the measures interfering with the rights guaranteed by this provision. In ascertaining whether this condition has been satisfied, the Court takes a comprehensive view”.

${ }^{81}$ In Di Palma v Victoria Square Property Co Ltd [1984] Ch 346, 361 to 362 a long lease was forfeit because of service charge arrears amounting to £299.36, together with a bailiff's fee of $£ 15$. The flat, at the time of forfeiture, was worth around $£ 30,000$. The judge commented (obiter) that such a loss was "a wholly disproportionate penalty".

${ }^{82}$ See Gladysheva v Russia [2012] HLR 19.

${ }^{83}$ Connors v United Kingdom (2005) 40 EHRR 9 at [81] to [83].

84 The rights contained Articles 8 to 11 of the ECHR allow interference with Convention rights only if objectively "necessary in a democratic society". That text is not replicated in A1P1; as a result, where A1P1 is engaged but Article 8 is not, the national legislature is afforded a wider margin of appreciation in tailoring the legislation to the pursuit of the legitimate aim. Indeed, the ECtHR has expressly rejected a test of strict necessity in the context of A1P1: see James $v$ United Kingdom (1986) 8 EHRR 123 at [51]. ${ }^{85}$ See the discussion above at p 8.
} 
question of remedies: where granting the possession order would be disproportionate, what should a judge do?

\subsection{The outcome of a successful human rights defence}

Where the heart of the proportionality argument is that the shared owner should not lose the investment value of the property, it may be appropriate to delay possession in order to give the shared owner time to sell the property. Once arrears had been repaid, this would leave the shared owner with a significant portion of her share in the property intact. The issue of remedies was discussed by Lord Neuberger in Pinnock, where he said:

... if domestic law justifies an outright order for possession, the effect of article 8 may, albeit in exceptional cases, justify (in ascending order of effect) granting an extended period for possession, suspending the order for possession on the happening of an event, or even refusing an order altogether. ${ }^{86}$

His Lordship also noted ${ }^{87}$ that this may require certain statutory provisions to be revisited, referring to section 89 of the Housing Act 1980. Section 89 limits the period for which a mandatory possession order can be postponed to 14 days, but in cases of "exceptional hardship" this period can be extended to six weeks. In Powell Lord Hope said it is not possible to read down section 89 to extend this period further but that, as no evidence had been given to show that six weeks was insufficient to meet cases of exceptional hardship, he declined to make a declaration of incompatibility. ${ }^{88}$ When discussing section 89, Lord Phillips noted that the effect of the strict section 89 time limit may "in rare cases" cause a judge to refuse possession when it would otherwise have been granted with a longer postponement. ${ }^{89}$

Given that more than a six week delay will almost certainly be needed in order to give the tenant of a shared ownership property time to sell, the effect of section 89 is that a court may need to refuse possession (or issue a declaration of incompatibility under section 4 of the HRA 1998). It is not yet possible to discern a common approach taken by lower courts to successful arguments of proportionality. Unhelpfully, some judges continue to refer to the old Gateways (a) and (b) (and indeed also appear to confuse or conflate the two); a distinction which is no longer helpful post-Pinnock. ${ }^{90}$ However, it does appear that the lower courts are willing to refuse possession orders where defences based on proportionality are successful. ${ }^{91}$

Of course, if the effect of the argument is to prevent possession at all this will mean that the housing association is stuck with an occupier who is not paying her dues. It may be

\footnotetext{
${ }^{86}$ Manchester City Council v Pinnock [2011] UKSC 6, [2010] 3 WLR 1441 at [62].

${ }^{87}$ Ibid at [63].

${ }^{88}$ Hounslow LBC v Powell [2011] UKSC 8, [2011] 2 WLR 287 at [64].

${ }^{89}$ Ibid at [103].

${ }^{90}$ For more detail on the gateways, see $\mathrm{p} 17$ below.

${ }^{91}$ See Chesterfield Borough Council v Bailey [2011] EW Misc 18 (CC); London Borough of Southwark v Hyacienth (CC, unreported) 22 December 2011; Southend-on-Sea v Armour (QBD, unreported) 18 October 2012.
} 
that after a certain length of time a court would say that it would now be proportionate to order possession, given that the shared owner had been given adequate time to sell the property; or it could simply issue a declaration that legislative change was needed to deal with the problem.

\section{Defences to possession proceedings: Administrative Law}

In English public law the principle of legality requires that public bodies must act lawfully when exercising their powers. This principle is enforced through the grounds of judicial review found in the speech of Lord Diplock in Council of Civil Service Unions $v$ Minister for the Civil Service: ${ }^{92}$ illegality, irrationality and procedural impropriety.

In most cases judicial review must be brought in the Administrative Court, ${ }^{93}$ but in Wandsworth London Borough Council $v$ Winder ${ }^{94}$ the House of Lords confirmed that a defendant to a civil action may challenge a public law decision in the course of defending that action, and may do so outside of the judicial review procedure. ${ }^{95}$ This allows tenants to raise defences to possession in the county court based on the principle of legality (provided, of course, that the body seeking possession is subject to the legality principle; in other words, that it is amenable to judicial review). ${ }^{96}$

This type of defence was formerly known as Gateway (b), following Lord Hope's classification of the two grounds for defending a possession order in Kay $v$ Lambeth $L B C$ :

(a) that the law which requires the court to make a possession order despite the occupier's personal circumstances is Convention-incompatible; and

(b) that, having regard to the occupier's personal circumstances, the local authority's exercise of its power to seek a possession order is an unlawful act within the meaning of section 6 [of the HRA 1998]. ${ }^{97}$

The Pinnock and Powell cases discussed above focused on the availability of a defence based on Gateway (a); the Supreme Court held in Pinnock that even when the ground for possession was mandatory, the law should be read (if possible) as allowing a

\footnotetext{
92 [1985] AC 374, 410.

93 Senior Court Act 1981, s 31. See also, O’Reilly v Mackman [1983] 2 AC 237. Judicial review is governed by Part 54 of the Civil Procedure Rules.

${ }_{94}^{9}$ [1985] AC 461.

${ }^{95}$ See also Clark v University of Lincolnshire and Humberside [2000] 1 WLR 1988.

${ }^{96}$ In R (Weaver) v London Quadrant Housing Trust [2008] EWHC 1377 (Admin), [2009] 1 All ER 17 the Divisional Court approached in the same way the questions of whether a body is subject to the HRA 1998 as a hybrid public authority and of whether that body was also subject to judicial review. This approach was approved by the Court of Appeal (see [2010] EWCA Civ 587, [2010] 1 WLR 363 at [83]). Therefore this chapter proceeds on the basis that housing associations which provide shared ownership leases are amenable to judicial review on conventional public law grounds.

97 [2006] UKHL 10, [2006] 2 AC 465 at [39].
} 
consideration of proportionality. Pinnock and Powell also reaffirmed the availability of defences based on principles of public law (formerly Gateway (b)), ${ }^{98}$ and that they could be used to challenge any prior decision on which the possession claim was founded (for example, the decision to serve a notice to quit) as well as the decision to bring possession proceedings. ${ }^{99}$

It is therefore open for a shared owner to utilise any argument based on the principle of legality that can be supported by the facts of their case. For instance, a shared owner may wish to argue that there is an element of procedural impropriety in the way in which the housing association has brought proceedings. Alternatively, she may wish to claim that the decision to bring possession proceedings is irrational; or that by doing so the housing association has acted in a way which goes against a legitimate expectation held by her. Under the following two headings those latter two arguments are considered.

\subsection{Irrationality}

The principle of legality requires that discretionary powers - such as the decision to bring possession proceedings - must be exercised rationally. Traditionally the test for whether a public body has acted rationally is whether the exercise of power is Wednesbury unreasonable. ${ }^{100}$ However, following Kay $v$ Lambeth $L B C^{101}$ and Doherty $v$ Birmingham City Council ${ }^{102}$ "there is a growing weight of opinion that judicial review is now wider than the traditional Wednesbury test" and "has been dubbed a Wednesbury Plus test”. ${ }^{103}$ The precise scope of Wednesbury Plus is unclear. ${ }^{104}$ It appears to allow a wider range of factors to be taken into account when considering whether the impugned decision was "one which no reasonable person would consider justifiable". ${ }^{105}$ For instance, Lord Hope in Doherty stated that the considerations that can be taken into account under Wednesbury plus include, for example, longevity of occupation. ${ }^{106}$

Applying this to the shared ownership context, an argument could be made that the decision to bring possession proceedings is Wednesbury unreasonable, in the light of the potential consequences of the possession order being granted: the shared owner will lose not only her home but also her share in the market value of the property. The difficulty with this argument is, of course, that the shared owner is in default with her rent and therefore, whilst the consequences of the possession order are unfortunate, the decision to bring proceedings cannot be said to be irrational.

\footnotetext{
${ }^{98}$ Manchester City Council v Pinnock [2011] UKSC 6, [2010] 3 WLR 1441 at [81].

${ }^{99}$ Hounslow LBC v Powell [2011] UKSC 8, [2011] 2 WLR 287 at [42]. See J Luba and others, “Defending Possession Proceedings" (2011) Legal Action Group (Online Update) 3, available at: http://www.lag.org.uk/files/93674/FileName/DPP7onlineupdateforweb.pdf (last accessed 28 May 2012).

100 Named after the case of Associated Provincial Picture Houses v Wednesbury Corporation [1948] 1 KB 223.

101 [2006] UKHL 10, [2006] 2 AC 465

102 [2008] UKHL 57, [2009] 1 AC 367.

103 S Nield, "Clash of the Titans: Article 8, Occupiers, and Their Home” in S Bright (ed), Modern Studies in Property Law: Volume 6 (Hart 2011) p 117.

${ }^{104}$ Liverpool City Council v Doran [2009] EWCA Civ 146, [2009] 1 WLR 2365 at [50].

105 Doherty v Birmingham City Council [2008] UKHL 57, [2009] 1 AC 367 at [55].

106 Ibid.
} 
Furthermore, Pinnock and Powell emphasise that the focus of a defence based on judicial review principles is primarily on the decision-making process, rather than on the potential effect that a possession order may have on the shared owner. Where an argument is based on the latter, the more appropriate defence is based on Article 8 (or, in the shared ownership scenario, A1P1), whereby the specific factual circumstances of the claim can be dealt with through a proportionality inquiry. This makes the potential for a successful defence based on rationality review limited in scope in the shared ownership context, as it will inevitably play second fiddle to challenges based on Convention rights of the type discussed above.

\subsection{Legitimate Expectations}

An alternative defence based on administrative law principles could be founded on the doctrine of legitimate expectations. This is a device used to prevent public authorities from defeating, without good reason, expectations of procedural or substantive rights they have created in citizens. The doctrine of legitimate expectations aims to prevent an abuse of power by a public body and balances the individual's expectations against the wider public interest. A legitimate expectation that has been generated can be defeated, but only where it is proportionate for the public authority to do so having regard to a legitimate aim pursued in the public interest. ${ }^{107}$

A potential claim under legitimate expectations would require a tenant to demonstrate that a public authority generated a legitimate expectation which is then defeated. One possible avenue to establish the expectation is through the shared ownership literature, which advertises "the normal rights and responsibilities of a full owner-occupier". ${ }^{108}$ The argument would be that this expectation was defeated by the loss of the home and the consequent loss of the investment value, which illustrate clearly that the tenant did not have the "normal rights and responsibilities" of a true owner. Potentially, this could be used to quash the decision to use a mandatory ground for possession as opposed to seeking forfeiture of the lease for non-payment of rent. However, given that Bright and Hopkins have doubted whether Miss Richardson would have succeeded with a private law claim to estoppel, ${ }^{109}$ it is improbable that a legitimate expectation claim would get very far: the threshold for generating a legitimate expectation is at least as high as that for an assurance of rights for estoppel. In Weaver the court noted that a legitimate expectation required a "clear, unambiguous and unqualified promise" ${ }^{110}$ whereas in

\footnotetext{
${ }^{107}$ See $R$ (on the application of Nadarajah) $v$ Secretary of State for the Home Department [2005] EWCA Civ 1363.

108 Homes and Communities Agency, Council of Mortgage Lenders and National Housing Federation, Shared Ownership: Joint Guidance for England (November 2010) para 5 (emphasis added). The same statement has appeared in previous versions of the Joint Guidance and, notably, has been retained even after the decision in Richardson v Midland Heart [2008] L \& TR 31. In contrast, a Key Information sheet annexed to model leases provides only that the leaseholder has "the normal responsibilities of a full owner": the sheet is accessible at http://www.homesandcommunities.co.uk/cfg?page_id=6169\&page=155 (last accessed 28 May 2012).

${ }^{109}$ See S Bright and N Hopkins, "Richardson v Midland Heart Ltd: low cost home ownership - legal issue of the shared ownership lease” [2009] Conveyancer and Property Lawyer 337.

${ }^{110} R$ (Weaver) v London and Quadrant Housing Trust [2008] EWHC 1377 (Admin), [2009] 1 All ER 17 at [87].
} 
Thorner $v$ Major the House of Lords variously described estoppel as requiring an assurance that is "clear and unequivocal" or simply "clear enough". ${ }^{111}$ In the absence of a housing association expressly informing a shared owner that it will not take possession proceedings against her, and then seeking to do so, it is difficult to see how a legitimate expectation could be generated in this context.

However, if a legitimate expectation was established, the issue would then become one of proportionality, akin to the ECHR arguments discussed above. The question would be whether the housing association acted to pursue a legitimate aim in a manner that is proportionate, balancing the defeat of the tenant's expectations against the wider public interest.

\subsection{The outcome of a successful administrative law defence}

The remedies available where a rationality or legitimate expectations argument is used to defend successfully possession proceedings are those of public law: the decision to use Ground 8 would be quashed, leaving the housing association to make the decision as to how to proceed against the tenant again. Public law claims do not generally provide a route to financial compensation. Damages are only usually available in judicial review proceedings where they could have been claimed in private law at the time the judicial review was sought; ${ }^{112}$ or a private law claim may arise following a successful judicial review (for example, where the effect of finding a public authority's conduct unlawful is that a tort has been committed). The latter possibility may have particular pertinence in relation to Ground 8. If judicial review of a decision to use Ground 8 is successfully obtained after repossession has been granted, the landlord's possession of the property would be a trespass from the time of the repossession for which damages would be available.

\section{Recovering the share of the property's market value}

The arguments canvassed in Parts 2 and 3 of this chapter assume that the shared owner can defend the possession claim and thus protect the "use value" of the property, at least long enough to enable her to attempt a sale of the property. But once the lease has been terminated, and the shared owner has lost the home, is there any way in which she can recover the "investment value"? Perhaps surprisingly the shared owner is unlikely to be able to recover her investment value under private law principles, as Bright and Hopkins have discussed elsewhere. ${ }^{113}$ Therefore, this chapter turns once more to arguments of human rights, and also briefly mentions the potential role that could be played by Ombudsmen.

\subsection{Article 8 and A1P1}

\footnotetext{
111 [2009] UKHL 18, [2009] 1 WLR 776.

112 Senior Courts Act 1981, s 31(4).

${ }^{113}$ S Bright and N Hopkins, "Richardson v Midland Heart Ltd: low cost home ownership - legal issue of the shared ownership lease” [2009] Conveyancer and Property Lawyer 337.
} 
Assuming that ending the lease involves a breach of A1P1 and/or Article 8, section 8(1) of the HRA 1998 gives a court broad powers to award "such relief or remedy, or make such order, within its powers as it considers just and appropriate". Section 8(4) of the HRA 1998 states that when determining whether to award damages, domestic courts must take into account the principles applies by the ECtHR in relation to the award of compensation under Article 41 of the ECHR. Article 41, which was introduced by the Eleventh Protocol to replace Article 50, reads as follows:

If the Court finds that there has been a violation of the Convention or the protocols thereto, and if the internal law of the High Contracting Parties allows only partial reparation to be made, the Court shall, if necessary, afford just satisfaction to the injured party.

It is therefore appropriate to consider, first of all, the ECtHR's approach to remedies under Article 41.

\subsubsection{The approach of the ECtHR to remedies}

Typically the approach of the ECtHR to a violation of Convention rights has been to issue a declaration to that effect. This reflects the fact that the ECHR is an international human rights treaty - in many cases the applicant's primary aim in bringing proceedings is put to an end the violation of her rights. In these situations, "just satisfaction" can be afforded without the payment of monetary compensation.

However, it is clear that the ECtHR retains a discretionary jurisdiction to award compensation in order to afford just satisfaction to the injured party. The principle of compensation is restitutio in integrum: the applicant is to be put back in the position he or she would have been in had the violation not occurred. It should be noted in this respect that in the jurisprudence of the ECtHR compensation awarded pursuant to the principle of restitutio in integrum is a loss-based award, in contra-distinction to a gainbased restitutionary one. ${ }^{114}$

The case law of the ECtHR in respect of its approach to the quantification of damages is not at all helpful. Practitioners and commentators searching for principles in this area are frequently frustrated. Lester and Pannick argue that the court simply makes an equitable assessment of the facts of the individual case; ${ }^{115}$ and a former judge of the ECtHR has been reported as stating privately that the court has no principles when it comes to assessing compensation. ${ }^{116}$ A report by the English and Scottish Law Commissions $^{117}$ distilled from the court's jurisprudence the following factors which may be taken into consideration when deciding whether to award compensation:

\footnotetext{
${ }^{114}$ Law Commission and Scottish Law Commission, Damages Under the Human Rights Act 1998 (Law Com No 266/Scot Law Com No 180, 2000) paras 3.19 to 3.21.

115 A Lester, D Pannick and J Herberg, Human Rights Law and Practice (3rd ed, LexisNexis 2009) para

2.8.4. See also J Varuhas, “A Tort-Based Approach to Damages under the Human Rights Act 1998” (2009) 72 Modern Law Review 750, 756.

${ }^{116}$ R Clayton and H Tomlinson, The Law of Human Rights: Volume 1 (2nd ed, OUP 2009) para 21.30.

${ }^{117}$ Law Commission and Scottish Law Commission, Damages Under the Human Rights Act 1998 (Law

Com No 266/Scot Law Com No 180, 2000).
} 
- The other measures taken by the public authority in remedying in the breach

- Whether a finding of a breach can constitute "just satisfaction" without the need for compensation

- Whether the loss suffered is sufficient to render an award necessary

- The seriousness of the violation

- The conduct of the respondent

- The conduct of the applicant

There may be cases where not even the payment of compensation can afford just satisfaction to the applicant. For example, in Gladysheva $v$ Russia the applicant was evicted from her flat by the state, in violation of Article 8 and A1P1. In assessing her damages under Article 41 the Court reiterated the principle of restitutio in integrum, and went on to state:

Consequently, having due regard to its findings in the instant case, and in particular having noted the absence of a competing third-party interest or other obstacle to the restitution of the applicant's ownership, the Court considers that the most appropriate form of redress would be to restore the applicant's title to the flat and to reverse the order for her eviction. Thus, the applicant would be put as far as possible in a situation equivalent to the one in which she would have been had there not been a breach of Article 8 of the Convention and Article 1 of Protocol No. 1 to the Convention. ${ }^{118}$

A similar award was made by the Grand Chamber in the context of an A1P1 violation in Brumarescu $v$ Romania ${ }^{119}$ and Papamichalopoulos $v$ Greece. ${ }^{120}$ In the latter case the court ordered the properties in issue to be returned to the applicants (and failing that, compensation reflecting the current market value of the house was to be paid).

It is clear, therefore, that the ECtHR has at its disposal a wide range of remedial orders which it can utilise when seeking to afford "just satisfaction" to the applicant. The principles that can be taken from the case law of the Court are that, first, in principle it is for the national authorities to decide the means by which restitutio in integrum is to be achieved - whether by compensation or otherwise; ${ }^{121}$ and second, where the national authority fails to afford just satisfaction to the applicant, the ECtHR is willing to make whatever order for redress that it feels appropriate.

\subsubsection{Damages under the HRA 1998}

The leading English case on damages under the HRA 1998 is $R$ (Greenfield) $v$ Secretary of State for the Home Department, where a unanimous appellate committee of the House of Lords held that domestic courts were not free to depart from the scale of

\footnotetext{
118 [2012] HLR 19 at [106].

119 (2001) 33 EHRR 36.

120 (1996) 21 EHRR 439.

${ }^{121}$ See Dixon $v$ United Kingdom (App No. 3468/10) (unreported), in which the ECtHR accepted that the national authority had provided the applicant with just satisfaction following a compensatory payment of $£ 3,000$, despite the applicant's argument that if Article 8 had been correctly applied in his case a possession order would never have been made.
} 
damages applied by the ECtHR (the argument was run by counsel that the courts could use domestic comparators in awarding damages). ${ }^{122}$ Therefore, domestic courts now operate a "mirror" approach to assessing damages under the HRA 1998, both in terms of how the discretion to award damages is to be exercised, and the scales of damages applied.

\subsubsection{Application to the shared ownership scenario}

Where a tenant has failed to defend possession proceedings (at all, or at least successfully) and has therefore lost her home in breach of A1P1 and/or Article 8, section 8 of the HRA 1998 requires the court to assess what relief or remedy should be granted. There appear to be two main options.

First, the court could follow the type of award made by the ECtHR in Gladysheva. This would involve quashing the possession order and restoring the shared owner's title. This could then enable the shared owner to sell the property (in the situation where retention is not financially viable) and by doing so recoup their investment. The shared owner may additionally seek compensation for non-pecuniary losses and costs and expenses. ${ }^{123}$ However, such an award may not be possible or practicable. For example, the property may have been resold following repossession or the shared owner may now be settled in a new home for which they have financial and contractual commitments as tenant. It is worth noting that in Gladysheva the court considered important the fact that there was no competing third-party interest that would have been prejudiced by the reversal of the order for eviction.

Secondly, the court could award damages. This is subject to section 8(3) HRA 1998, which provides that damages can only be awarded if, after consideration of:

(a) any other relief or remedy granted, or order made, in relation to the act in question (by that or any other court), and

(b) the consequences of any decision (of that or any other court) in respect of that act,

the court is satisfied that the award is necessary to afford just satisfaction to the person in whose favour it is made.

As previously mentioned, following section 8(4) HRA 1998 and Greenfield, domestic courts draw heavily upon ECtHR principles when assessing whether to make an award for damages (and if so, to what amount). In the shared ownership context the nature of the loss suffered means that compensation would be required to provide just satisfaction

\footnotetext{
122 [2005] UKHL 14, [2005] 1 WLR 673. Section 8(4) of the HRA 1998 obliges domestic courts to take account of ECtHR principles in relation to the award of compensation under Article 41 of the Convention. The Greenfield decision is unpopular: the English and Scottish Law Commissions have recommended that principles of tort law should be drawn upon when awarding damages: Law Commission and Scottish Law Commission, Damages Under the Human Rights Act 1998 (Law Com No 266/Scot Law Com No 180, 2000). See also J Varuhas, “A Tort-Based Approach to Damages under the Human Rights Act 1998” (2009) 72 Modern Law Review 750.

123 "Just satisfaction” is not confined to pecuniary loss: Law Commission and Scottish Law Commission, Damages Under the Human Rights Act 1998 (Law Com No 266/Scot Law Com No 180, 2000) para 3.22.
} 
to the shared owner. As regards the shared owner's pecuniary loss, the principle of restitutio in integrum requires that the tenant be restored to the position she would have been in if the violation had not occurred. That would seem to allow an award for the tenant's share of the market value of the property at the time of the repossession (the time of the violation), less arrears owed to the housing association. ${ }^{124}$

\subsection{Ombudsmen}

If Richardson $v$ Midland Heart ${ }^{125}$ represents the legally correct outcome, it may nonetheless be that there remains an "injustice" of the sort an ombudsman could investigate. Both the Housing Ombudsman ${ }^{126}$ and the Parliamentary Ombudsman might potentially have jurisdiction. The Housing Ombudsman may well be able to investigate, for example, the decision to seek possession under Ground 8 and the accuracy of information provided by the housing association in respect of a shared ownership scheme. ${ }^{127}$

There is not space here to consider these possibilities further. In any event the Ombudsman service hardly seems the appropriate forum in which to seek redress for the fundamental issues relating to the rights of shared owners given that they stem from problematic law rather than poor administration.

\section{Conclusion}

Shared ownership has used a legal model - the long lease - that was not designed for the sharing of ownership. This has had unanticipated consequences which are exposed by the injustice of the Richardson $v$ Midland Heart case. It is unlikely that had anyone given serious consideration to the issue in advance that they would have intended shared owners to be vulnerable to repossession on the grounds within the Housing Act 1988. It is much more likely that the usual termination provisions for long leases - forfeiture, with the accompanying possibility of relief against forfeiture on terms - would have been considered appropriate. It is also the case that the source of the injustice is the failure to deliver what shared ownership promises - "the normal rights and responsibilities of a full owner-occupier". This includes, at its core, an expectation that the financial investment in the home is 'their capital'. The product has been mis-sold and the responsibility for this is spread amongst government and social landlords. But even if this is recognised, it does not solve the problem that arises under the model that has been used. Hence, our aim in this chapter has not been to consider alternative models for LCHO, or ways in which the existing model could be improved upon. It has a much more limited goal of finding a way to remedy the injustice that Miss Richardson and others in her position suffer. It may be considered surprising that private law cannot help, and that there is more promise in human rights arguments. The application of

\footnotetext{
${ }^{124}$ This also seems to follow the award in Brumarescu v Romania (2001) 33 EHRR 36, save to the extent that the ECtHR based the award on the current market value.

125 [2008] L \& TR 31.

126 The HOS was created by section 51 and schedule 2 to the Housing Act 1996. Under the Localism Act 2011 the jurisdiction of the HOS extends to incorporate local housing authorities from 1 April 2013.

${ }^{127}$ And the jurisdiction includes power to order the payment of compensation: Housing Act 1996, sch 2, paras 7(1) and 7(2)(a).
} 
Article 8 and A1P1 is not beyond doubt but if, as we suggest, they apply to possession proceedings in the shared ownership context we are left with the question of whether it is disproportionate to deny Miss Richardson the opportunity to recover her investment. The answer to us is clear: she should at least get back her share of the property's value. 